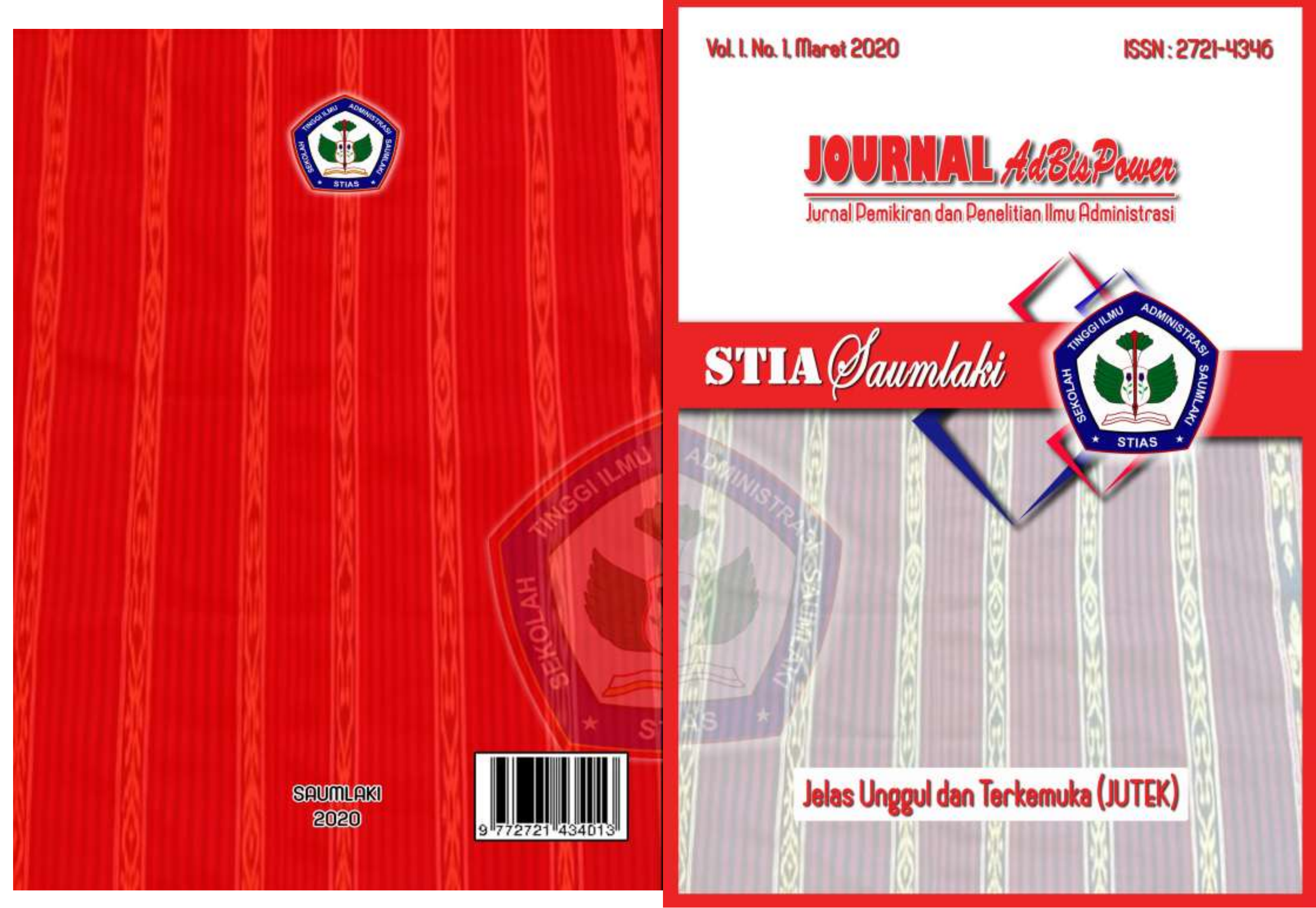




\title{
REKRUTMEN APARATUR DESA TERHADAP PENINGKATAN KINERJA PEMERINTAH DI DESA ANALUTUR, KECAMATAN BABAT TIMUR KABUPATEN MALUKU BARAT DAYA
}

\author{
Oleh: \\ Yulius Luturmas \\ (Dosen STIA Saumlaki)
}

\begin{abstract}
ABSTRAK
Aparatur Pemerintah Desa Analutur Kabupaten Maluku Barat Daya kurang prima,dan salah satu faktor yang berpengaruh adalah Rekrutmen Aparatur Desa tidak dilaksanakan secara baik. Dengan menggunakan metode penelitian assosiatif yang menghubungkan rekrutmen dan kinerja. Data dikumpulkan dengan melakukan wawancara berstruktur, observasi, studi kepustakaan, dan membagi daftar pertanyaan kepada responden yang berjumlah 50 orang. kemudian dianalisa secara kuantitatif (Analisis Statistik Korelasi Product Moment). Hasilnya menunjukan bahwa korelasi antara rekrutmen aparatur terhadap kinerja pemerintah di Desa Analutur Kabupaten Maluku Barat Daya adalah sebesar 0,857. Berdasarkan koefisien determinasi membuktikan rekrutmen memberikan kontribusi terhadap kinerja sebesar 62,2 \% dan sisanya 37,8\% ditentukan oleh variabel lain yang konstan. Selanjutnya dilakukan uji signifikan dengan menggunakan t-hitung pada tingkat kepercayaan 0,05\%. Dan hasilnya t-hitung sebesar 8,888 > t-tabel 1,68 yang artinya hipotesa diterima.
\end{abstract}

Kata Kunci : Rekruitmen Aparatur, Peningkatan Kinerja dan Desa

\begin{abstract}
The Village Government apparatus of Analutur, Southwest Maluku Regency is not excellent, and one of the influencing factors is that the Village Apparatus Recruitment is not carried out properly. By using associative research methods that link recruitment and performance. Data were collected by conducting structured interviews, observations, literature study, and distributing a list of questions to 50 respondents. then analyzed quantitatively (Product Moment Correlation Statistical Analysis). The results show that the correlation between apparatus recruitment and government performance in Analutur Village, Southwest Maluku Regency is 0.857. Based on the coefficient of determination, it is proven that recruitment contributes to performance by $62.2 \%$ and the remaining $37.8 \%$ is determined by other variables which are constant. Furthermore, a significant test was carried out using tcount at a confidence level of $0.05 \%$. And the result is t-count of $8.888>\mathrm{t}$-table 1.68 , which means that the hypothesis is accepted.
\end{abstract}

Keywords: Apparatus Recruitment, Performance and Village Improvement 


\section{PENDAHULUAN}

Desa sebagai unit terendah dalam struktur pemerintahan Indonesia telah ada sejak dahulu kala dan murni Indonesia bukan bentukan Belanda. Terbentuknya desa diawali dengan terbentuknya kelompok masyarakat akibat sifat manusia sebagai makhluk sosial, dorongan kodrat, atau sekeliling manusia, kepentingan yang sama dan bahaya dari luar. Istilah desa berasal dari bahasa Sanskerta yang artinya tanah tumpah darah.

Dalam menjalankan roda pemerintahan baik itu ditingkat pusat, provinsi, kabupaten bahkan desa/dusun perlu dipimpin oleh orang yang biasanya kita kenal dengan istilah pemimpin. Sosok pimpinan yang baik dapat diperoleh ketika dalam tahapan-tahapan pemilihan pemimpin tersebut dilaksanakan secara baik pula. Bahwa untuk menghindari resistensi dalam masyarakat serta mewujudkan proses pencalonan, pemilihan, pengesahan pengangkatan dan pemberhentian Kepala Desa di Desa Analutur Kabupaten Maluku Barat Daya yang demokratis secara langsung, umum, bebas, rahasia, jujur, dan adil, perlu dilakukan penyesuaian ketentuan mengenai pemilihan Kepala Desa dengan perkembangan dan tuntutan penyelenggaraan otonomi desa.
Terletak di Provinsi Maluku kabupaten Maluku barat daya Kecamatan Babar Timur terdapat sebuah desa kecil yang bernama Desa Analulur yang mempunyai penduduk 420 jiwa yang terdiri atas \pm 90 kepala keluarga. Desa yang memiliki nilai adat yang tinggi sehingga dari awal terbentuknya desa Analutur sampai sekarang ini masih kental dengan adat-istiadatnya.

Karena adat istiadat yang masih kental tersebut, maka dalam menjalankan sistem pemerintahan di Desa Analutur juga sangat ditentukan oleh faktor adat. Dalam menjalankan roda pemerintah di desa Aanalutur haruslah berpatokan terhadap aturan adat yang mengharuskan soa Onarloy dan soa Oraile yang mempunyai posisi yang tepat sebagai pemimpin desa tersebut.

Dalam proses pelaksanaan rekrutmen aparatur desa, maka kepala desa menggunakan metode/cara perekrutan secara tertutup. Dimana kepala Desa mengangkat aparatur desa dengan melihat orang-orang yang dipandang cakap memilk kematangan intelektual, berpengalaman, sepaham, dan dapat bekerjasama dan dapat membantu kepala desa dalam menjalankan tugastugasnya. Sehingga dalam sistem perekrutan secara tertutup ini, kepala desa tidak dapat diinterfensi oleh siapapun dan 
merupakan hak prerogative kepala desa dalam mengangkat dan memberhentikan aparaturnya. Hal inilah yang menjadi dasar dilakukknya penelitian tentang Rekruitmen Aparatur Desa terhadap Kinerja Pemerintah Desa di Desa Analutur Kecamatan Babar Timur Maluku Barat Daya.

\section{LANDASAN TEORI}

\section{Rekrutmen}

Henry Simamora (1997:212) dalam buku koleksi digital Universitas Kristen Petra menyatakan bahwa Rekrutmen

(Recruitment) adalah

"Serangkaian aktivitas mencari dan memikat pelamar kerja dengan motivasi, kemampuan, keahlian, pengalaman, dan pengetahuan yang diperlukan guna menutupi kekurangan yang diidentifikasi dalam perencanaan kepegawaian”.

Dalam hal ini kualitas calon pekerja sangat dibutuhkan dalam menjalin atau menemukan calon aparatur yang sesuai dengan kriteria-kriteria rekrutmen agar dapat menghasilkan aparatur ysng handal dan berkualitas.

Gomes (1995:105) menyatakan bahwa rekrutmen merupakan proses mencari, menemukan dan menarik para pelamar untuk dipekerjakan dalam dan oleh suatu organisasi.

Rekrutmen merupakan proses komunikasi dua arah. Pelamar-pelamar menghendaki informasi yang akurat mengenai seperti apakah rasanya bekerja di dalam organisasi bersangkutan. Organisasi-organisasi sangat menginginkan informasi yang akurat tentang seperti apakah pelamar-pelamar tersebut jika kelak mereka diangkat sebagai pegawai.

Menurut Schuler dan Jackson (1997) dalam Nanang Nuryanta (2008) rekrutmen antara lain meliputi :

"Upaya pencarian sejumlah calon karyawan yang memenuhi syarat dalam jumlah tertentu sehingga dari mereka perusahaan dapat menyeleksi orang-orang yang paling tepat untuk mengisi lowongan pekerjaan yang ada".

Berdasarkan teori ini, kepala desa terpilih melakukan pencarian orang-orang yang dikatakan mampu dalam menjalankan tugas-tugas pemerintahan desa untuk direkrut dan diposisikan pada bidang tugas yang ada di dalam lingkup pemerintahan desa tersebut.

Rekrutmen didefinisikan sebagai pelaksanaan atau aktivitas organisasi awal dengan tujuan untuk mengidentifikasi dan mencari tenaga kerja yang potensial.

Menurut Schermerhorn, 1997

Rekrutmen (Recruitment) adalah

"proses penarikan sekelompok kandidat untuk mengisi posisi yang lowong. Perekrutan yang efektif akan membawa peluang pekerjaan kepada perhatian dari orang-orang yang berkemampuan dan 
keterampilannya memenuhi spesifikasi pekerjaan":.

Menurut Mathis (2006), perekrutan adalah

\begin{abstract}
"Proses penarikan sejumlah calon yang berpotensi untuk diseleksi menjadi pegawai atau juga diartikan yaitu penarikan (recruitment) adalah masalah penting dalam pengadaaan tenaga kerja. setelah rekrutmen dilakasanakan, maka pelaksanaan seleksi. Seleksi ini didasarkan pada spesifikasi tertentu dari setiap perusahan yang bersangkutan".
\end{abstract}

Sistem rekrutmen yang tepat akan menemukan " The Right Man On The Right Place”.

Kegagalan dalam melakukan penempatan dapat menjadi penghambat bagi proses pencapaian tujuan organisasi. Sistem rekrutmen harus benar-benar dilakukan karena menyangkut proses jangka panjang dari tenaga kerja sehingga orang yang tepat akan diperoleh. Program rekrutmen dan penempatan kerja yang tepat dan sesuai dengan kebutuhan organisasi maka tujuan perusahan dapat tercapai. Berdasarkan defenisi di atas, dapat diketahui bahwa sistem rekrutmen yang baik, maka akan mempengaruhi penempatan kerja dalam suatu organisasi.

Biasanya dikenal dua jenis rekrutmen yaitu rekrutmen terbuka dan tertutup. Rekrutmen terbuka umumnya digunakan untuk merekrut staf yang tidak memerlukan kualifikasi khusus.

Sedangkan rekrutmen tertutup biasanya dilakukan untuk posisi dengan kualifikasi khusus dan hanya orang-orang tertentu yang dapat mengisinya. Proses rekrutmen antara lain adalah informasi lowongan, tes ketrampilan/keahlian sesuai posisi yang dibutuhkan, bahasa daerah (jika organisasi melakukan pendampingan di daerah yang rata-rata penduduknya tidak bisa berbahasa Indonesia) atau tes bahasa Inggris, menulis proposal dan report, psikotes, dan terakhir wawancara.

Menurut Simamora (1997) untuk menciptakan suatu sistem rekrutmen yang efektif para manajer dan manajer sumber daya manusia, seyogyanya menerapkan beberapa hal, antara lain:

1. Mendiagnosis seefektif mungkin (berdasarkan kendala waktu, sumber daya finansial, dan ketersediaan staf pelaksana yang ada) faktor-faktor lingkungan dan organisasional yang mempengaruhi posisi yang perlu diisi dan aktivitas rekrutmen;

2. Membuat deskripsi, spesifikasi, dan standart kinerja yang rinci;

3. Menentukan tipe individuindividu yang sering dikaryakan oleh organisasi dalam posisi yang sama;

4. Menentukan kriteria-kriteria rekrutmen;

5. Mengevaluasi berbagai saluran dan sumber rekrutmen;

6. Menyeleksi sumber rekrutmen yang kemungkinan menghasilkan kelompok kandidat yang paling 
besar dan paling sesuai pada biaya yang serendah mungkin;

7. Mengidentifikasikan saluransaluran rekrutmen untuk membuka sumber-sumber tersebut, termasuk penulisan iklan, menjadwalkan program rekrutmen;

8. Menyeleksi saluran rekrutmen yang paling efektif biaya;

9. Menyusun rencana rekrutmen yang mencakup daftar aktivitas dan daftar untuk menerapkannya;

Sebelum organisasi dapat mengisi sebuah kekosongan pekerjaan, organisasi tersebut mestilah mencari orang-orang yang tidak hanya memenuhi syarat untuk posisi tersebut, namun juga menginginkan pekerjaan itu. Melalui rekrutmen organisasi dapat melakukan komunikasi dengan pihak-pihak tertentu untuk memperoleh sumber daya manusia yang potensial, sehingga akan banyak pencari kerja dapat mengenal dan mengetahui organisasi yang pada akhirnya akan memutuskan kepastian atau tidaknya dalam bekerja. Jadi rekrutmen adalah proses mencari, menemukan dan menarik para pelamar untuk dipekerjakan dalam suatu organisasi.

\section{Pengertian Seleksi}

Seleksi maksudnya pemilihan tenaga kerja yang sudah tersedia. Seleksi pada dasarnya bertujuan untuk mendapatkan tenaga kerja yang memenuhi syarat dan memiliki kualifikasi yang sesuai dengan deskripsi pekerjaan yang ada atau sesuai dengan kebutuhan organisasi.Tujuan seleksi adalah mendapatkan tenaga kerja yang paling tepat untuk memangku suatu jabatan tertentu. Mengarah pada tujuan seleksi yang demikian itu, setiap organisasi yang bersangkutan senantiasa akan berusaha dengan biaya yang serendah mungkin dengan menggunakan cara yang paling efisien, tetapi efektif.

Tenaga kerja adalah aset atau kekayaan utama dari setiap organisasi. Peran tenaga kerja sangat menentukan berhasil tidaknya perusahaan mencapai sasarannya. Organisasi harus selalu berusaha untuk memperoleh dan menempatkan tenaga kerja yang qualified pada setiap jabatan dan pekerjaan supaya pelaksanaan pekerjaan lebih berdaya guna serta berhasil guna. Pengertian atau definisi seleksi antara lain adalah sebagai berikut: Seleksi adalah usaha pertama yang harus dilakukan organisasi untuk memperoleh tenaga kerja yang qualified dan komponen yang akan menjabat serta mengarjakan semua pekerjaan pada organisasi. Pelaksanaan seleksi harus dilakukan secara jujur, cermat, dan obyektif upaya karyawan yang diterima benar-benar qualified untuk menjabat dan melaksanakan pekerjaan. Dengan pelaksanaan seleksi yang baik, karyawan 
yang diterima akan lebih qualified sehingga pembinaan, pengembangan, dan pengaturan tenaga kerja menjadi lebih mudah.

Seleksi merupakan "proses pemilihan dari sekelompok pelamar individu yang paling cocok untuk posisi tertentu dalam sebuah organisasi. Seleksi tenaga kerja adalah suatu proses menemukan tenaga kerja yang tepat dari sekian banyak kandidat atau calon yang ada".

Tahap awal yang perlu dilakukan setelah menerima berkas lamaran adalah melihat daftar riwayat hidup milik pelamar. Kemudian dilakukan penyortiran antara pelamar yang akan dipanggil dengan yang gagal memenuhi standar suatu pekerjaan. Lalu berikutnya adalah memanggil kandidat terpilih untuk dilakukan ujian test tertulis, wawancara kerja/interview dan proses seleksi lainnya. Mengapa dilakukannya penyeleksian tenaga kerja?

Karena, kegiatan seleksi ini sangat penting di dalam proses manajemen sumber daya manusia, apabila suatu perusahaan tidak teliti dan tidak cermat dalam seleksi ini kemungkinan akan terjadi penerimaan tenaga kerja yang tidak sesuai dan tidak cocok dengan jabatan pekerjaan yang dipercayakan kepadanya, sehingga dia tidak bisa bekerja secara efisien dan efektif dan kemungkinan harus dikeluarkan biaya dan waktu yang cukup lama untuk mengikutkannya pada tugas belajar dan pelatihan. Karena suatu perusahaan atau organisasi tidak selalu memiliki karyawan-karyawan yang berkualitas maka sebuah organisasi tersebut memiliki kemungkinan yang lebih kecil untuk mancapai keberhasilan.

Maka dari itu pelaksanaan seleksi harus benar-benar diaplikasikan secara teliti untuk menghindari segala cara-cara kolusi dan nepotisme yang akan merugikan organisasi usaha. Sering juga dipertanyakan dalam manajemen sumber daya manusia, apakah kegiatan rekrutmen dengan seleksi harus dipisahkan dalam fungsi manajemen sumber daya manusia atau dapat digabung menjadi satu fungsi seorang manajer? Jawabannya adalah tergantung pada besar kecilnya organisasi dan jumlah karyawan yang akan direkrut dan diseleksi.

Apabila jumlah tenaga kerja yang akan diseleksi cukup besar sampai ribuan orang, misalnya seperti penerimaan Pegawai Negeri suatu departemen, maka sebaiknya fungsi rekrutmen dan seleksi sumber daya manusia dipisahkan, akan tetapi kalau pegawai yang direkrut hanya beberapa orang saja seperti pada perusahaan kecil maka fungsi rekrutmen dan seleksi tersebut tidak perlu dipisahkan dan dapat dikerjakan oleh seorang 
Manajer Sumber Daya Manusia. Fungsi Manajemen Sumber Daya Manusia, Manajemen Sumber Daya Manusia sebenarnya memiliki beberapa fungsifungsi. Dimana fungsi-fungsi tersebut saling terkait satu sama lain, dan aktivitasaktivitas yang dijalankan oleh Manajemen Sumber Daya Manusia yang sangat cocok dengan fungsi-fungsi yang dimilikinya, yang bertujuan dengan peningkatan produktivitas, kualitas kehidupan kerja dan pelanyanan

\section{Pengertian Kinerja}

Pengertian manajemen sumber daya manusia dapat dikatakan sebagai manajemen personalia (Aparatur Desa). Yang membedakan keduanya hanyalah pada cara pendekatan. Apabila dalam manajemen personalia (Aparatur Desa) sebagai faktor produksi, maka di dalam manajemen sumber daya manusia, tenaga kerja selain merupakan harta atau aset dan juga mitra organisasi dalam menjalankan aktifitasnya/Kegiatan organisasi dalam seluruh upaya pencapaian tujuan keberhasilannya. Kinerja merupakan hal yang sangat penting bagi setiap organisasi termasuk Pemerintah di Desa Analutur Kecamatan Babar Timur Kabupaten Maluku Barat Daya dapat tetap eksis sesuai dengan tugas pokok dan fungsinya, baik dilihat dari segi ketepatan waktu, penyelesaian tugas, kualitas, maupun kuantitas hasil pelaksanaan tugas yang dibebankannya dapat tercapai dengan memenuhi ketiga hal di atas. Untuk membahas masalah kinerja, hal pertama yang perlu diperhatikan adalah mengenai pengertian kinerja.

Menurut Kamus Besar Bahasa Indonesia (1991) kinerja adalah suatu yang dicapai, prestasi yang diperhatikan,kemampuan kerja.

Berdasarkan pengertian kinerja tersebut di atas, dapat disimpulkan bahwa

"kinerja dapat diartikan sama dengan prestasi kerja. Prestasi kerja dapat pula diartikan sebagai keseluruhan hasil pelaksanaan tugas yang dilakukan oleh seorang pegawai dimana hasil pelaksanaaannya benar-benar sesuai dengan tugas yang telah diberikan kepadanya, baik secara kualitas maupun kuantitas."

Menurut Siagian menyatakan ciri-ciri kinerja meliputi:

a. Sifat agresif ;

b. Daya tahan terhadap tekanan;

c. EnergI fisik;

d. Kreatifitas;

e. Kepercayaan pada diri sendiri;

f. Kemampuan menyesuaikan diri;

g. Kepemimpinan;

h. Integrasi pribadi;

i. Keseimbangan emosional;

j. Ketepatan waktu;

k. Prakarsa;

1. Komunikasi. 
kinerja adalah kemampuan seseorang dalam mencapai hasil kerja yang baik atau lebih menonjol kearah tercapainya tujuan organisasi.

Kinerja dinyatakan sebagai

"hasil kerja seseorang dalam melaksanakan tugas yang dibebankan kepadanya dengan didasarkan pada kecakapan, pengalaman, kesungguhan, dan waktu. Disamping itu kinerja merupakan gabungan dari tiga faktor penting yaitu :

1. kemampuan atau minat seseorang pekerja;

2. kemampuan penerimaan atas penjelasan delegasi dan peran serta tingkahlaku motivasi seorang pekerja; dan

3. semakin tinggi prestasi pegawai yang bersangkutan."

Siagian (2002) mengartikan prestasi kerja adalah pencapaian pelaksanaan kegiatan yang dilakukan oleh organisasi sesuai dengan beban tugas baik kualitas maupun kuantitas yang didasarkan pada analisa jabatan. Dengan demikian, seseorang dapat dikatakan berprestasi apabila yang besangkutan telah berhasil melaksanakan tugasnya sesuai dengan beban yang diberikan kepadanya.

\section{Sementara Alaslan (2021: 82)} mendefenisiskan kinerja sebagai tingkat kematangan aparatur dalam menyelesaikan tugas dan tanggung jawabnya dengan kemampuan intelektual (intelectual ability) yaitu kemampuan yang dibutuhkan untuk melakukan berbagai aktifitas mental berfikir, menalar dan memecahkan masalah dan Kemampuan fisik (physycal ability) yaitu kemampuan melakukan tugas-tugas yang menurut stamina, ketrampilan, kekuatan dan karakteristik serupa.

Ada dua faktor yang mempengaruhi prestasi kerja yaitu faktor individu dan faktor lingkungan. Faktor individu yang dimaksud adalah:

1. Usaha (effort) yang menujukan sebuah sinergi fisik dan mental yang digunakan dalam menyelenggarakan tugas;

2. Abilities yaitu sifat-sifat personal yang diperlukan untuk melaksanakan suatu tugas;

3. Role/task perception yaitu segala perilaku dan aktifitas yang dirasa perlu oleh individu untuk menyelesaikan suatu pekerjaan;

Adapun faktor-faktor lingkungan yang mempengaruhi prestasi kerja adalah :

1. Kondisi fisik;

2. Peralatan;

3. Waktu;

4. Material;

5. Pendidikan;

6. Supervise;

7. Desain organisasi;

8. Pelatihan;

9. keberuntungan;

Berdasarkan rumusan mengenai pengertian kinerja tersebut di atas, terdapat persamaan pengertian sebagai berikut : 
1. Prestasi kinerja merupakan hasil kerja.

2. Hasil kerja dilihat baik dari segi kualitas maupun kuantitas.

3. Hasil pelaksanaan tugas sesuai dengan yang diberikan kepada pegawai yang bersangkutan.

Dari berbagai pendapat di atas, dapat disimpulkan bahwa untuk mengukur kinerja atau prestasi kerja adalah hasil kerja aparatur baik dilihat dari segi kualitas maupun kuantitas.

Jadi kinerja diuraikan sebagai hasil kerja yang dicapai oleh seseorang atau sekelompok orang dalam suatu organisasi.

"Kinerja pegawai mempunyai hubungan erat dengan kinerja organisasi, karena tujuan organisasi hanya dimungkinkan karena ada upaya para pelaku yang terdapat dalam organisasi. Oleh karena itu, kinerja indifidu adalah kinerja organisasi, (Gibson 1996).”

\section{Efektifitas kerja}

Tiap organisasi selalu dihadapkan pada persoalan keterbatasan sumber daya manusia dalam mencapai tujuannya.Interaksi antar berbagai sumber daya manusia dalam mencapai tujuannya. Interaksi antar berbagai sumber daya tersebut harus dikelola dengan baik sehingga dapat mencapai sasaran secara efektif dan efesien. Secara sederhana efektivitas kerja dapat didefenisikan sebagai kemampuan untuk melakukan sesuatu tepat pada sasaran. efektivitas adalah:

"seberapa jauh suatu program telah mencapai tujuan yang diinginkan. Penilaian efektifitas didasarkan atas tujuan program sesuai dengan keinginan pembuat peraturan perundang-undangan yang berlaku. Dengan demikian pelaksanaan kegiatan dinyatakan efektif jika hasil yang dicapai sesuai dengan peraturan yang berlaku".

Efisiensi berkenaan hubungan antara produk yang dihasilkan dengan sumber daya yang digunakan. Penilaian diarahkan pada kecocokan, kelayakan, kataatan atas peraturan yang berlaku. Dengan demikian pelaksanaan kegiatan dinyatakan efisien jika pencapaian hasil kegiatan sesuai dengan peraturan yang berlaku.Dari uraian tersebut dapat disimpulkan kegiatan dinyatakan efektif dan efisien jika hasil yang dicapai dan pelaksanaan kegiatan sesuai dengan peraturan yang berlaku.

Efektifitas adalah suatu perbandingan antara kinerja unsur-unsur manajemen dengan tujuan yang ditetapkan dan efisiensi adalah suatu perbandingan antara manfaat yang diperoleh dengan biaya yang dikeluarkan.

Menurut Drs. Soekarno K. dalam bukunya yang berjudul Dasar-Dasar 
Manajemen bahwa yang dimaksud dengan efisiensi ialah perbandingan yang terbaik antara masukan (input) dan keluaran (output), atau antara daya usaha dan hasil, atau antara "pengeluaran" dan pendapatan. Dalam pengertian manajemen yang sehat sudah tersimpul pengertian efisiensi dan efektifitas, dalam arti bahwa segala sesuatu dikerjakan dengan berdayaguna artinya dengan tepat, cepat, hemat, dan selamat.

1. Tepat;

Kena sasaran, apa yang dikehendaki tercapai, atau apa yang dicita-citakan menjadi kenyataan.

2. Cepat;

Tidak menghabiskan waktu yang tidak perlu, selesai tepat pada waktunya atau sebelum waktu yang ditetapkan.

3. Hemat;

Dengan biaya yang sekecilkecilnya, tanpa terjadi pemborosan dalam bidang apapun.

4. Selamat;

segala sesuatu sampai pada tujuan yang dimaksud tanpa mengalami hambatanhambatan, kelambatan- kelambatan, ataupun

kemacetan- kemacetan.

"suatu keadaan dalam mencapai tujuan. Manajemen yang efektif perlu disertai dengan manajemen yang efisien.Tercapainya, tujuan mungkin hanya dapat dilakukan dengan penghamburan dan, oleh karena itu manajemen tidak boleh hanya diukur dengan efektivitas tetapi juga diperlukan efisiensi".

Sedangkan menurut Maryoto (2007) Efektivitas adalah

"suatu yang berhubungan dengan hasilhasil yang dicapai misalnya pemain bola yang efektif adalah angka rata-rata pukulan bolanya terbaik pada masa akhir pertandingan, begitu juga pejabat pimpinan yang efektif adalah seseorang yang mencapai angka tertinggi bila dinilai dari hasil-hasil yang dicapai".

Selanjutnya menurut The Liang Gie, dalam bukunya yang berjudul Administrasi Perkantoran Modern bahwa pengertian efisiensi kerja adalah

"perbandingan terbaik antara suatu kerja dengan hasil yang dicapai oleh kerja itu. Selanjutnya bilamana suatu kerja dianalisis, dapatlah dibedakan dalam 2 segi, yaitu intinya dan susunannya. Intinya ialah rangkaian aktivitasaktifitasnya itu sendiri yang wujudnya mengikuti tujuan yang hendak dicapai, sedang yang dimaksud dengan susunannya ialah cara-caranya rangkaian aktivitasaktivitas itu dilakukan. Jadi, setiap kerja tentu mencakup sesuatu cara tertentu dalam melakukan tiap-tiap aktivitas, apapun tujuan dan hasil yang ingin dicapai dengan kerja itu." 
Efektivitas merupakan unsur pokok aktivitas organisasi dalam mencapai tujuan atau sasaran yang telah ditentukan sebelumnya. Bila dilihat dari aspek segi keberhasilan pencapaian tujuan organisasi. Selanjutnya dari aspek kecepatan waktu, maka efektivitas tercapainya berbagai sasaran yang telah ditentukan tepat pada waktunya dengan menggunakan sumbersumber tertentu yang disediakan untuk melaksanakan berbagai kegiatan dalam program yang telah disusun sebelumnya.

\section{METODOLOGI PENELITIAN}

Metode yang digunakan dalam penelitian ini adalah metode penelitian kuantitatif, dengan jenis penelitian asosiatif untuk mengetahui hubungan atau pengaruh antara dua variabel atau lebih. Yang menjadi lokus dalam penelitian ini yaitu Desa Analutur Kecamatan Babar Timur Maluku Barat Daya.

Adapun sampelnya sebanyak 50 orang responden yaitu $12 \%$ dari total populasi dimana penulis menarik sampel dengan menggunakan acak sederhana (Random Sampling) merupakan orangorang yang mempunyai peranan di desa Analutur yang terdiri dari unsur aparatur desa, anggota BPD, anggota Angkatan Muda, Majelis Jemat, Guru, dan Kepala Soa. selanjutnya data dikumpulakan dengan menggunakan kusioner yang berupa daftar pertanyaan berupa multiple choice dengan skala likert, observasi, wawancara dengan kepustakaan.

Kemudian untuk menguji pengaruh kedua variabel pokok dalam penelitian ini digunakan Analisis Statistik Korelasi Product Moment (Sugiono, 2003:212) sebagai berikut

$$
r_{x y}=\frac{n\left(\sum x y\right)-\left(\sum x\right)\left(\sum y\right)}{\sqrt{\left\{n \sum x^{2}-\left(\sum x\right)^{2}\right\}\left\{n \sum y^{2}-\left(\sum y\right)^{2}\right\}}}
$$

Dimana :

$$
\begin{aligned}
& r_{x y=} \text { Koefisien Korelasi } \mathrm{r} \\
& n=\text { Jumlah sampel } \\
& \mathrm{x}=\text { Skor dalam distribusi } \\
& \text { variabel X (Rekrutmen) } \\
& \mathrm{y}=\text { Skor dalam distribusi } \\
& \text { variabel Y (Kinerja) }
\end{aligned}
$$

Selanjutnya untuk mengetahui apakah hubungan tersebut signifikan atau tidak perlu dilakukan uji signifikansi dengan menggunakan rumus t-thitung pada taraf signifikan $5 \%$ dengan rumus sebagai berikut (Sudjana $1983: 48$ )

$$
\text { t. hitung }=\frac{r \sqrt{n-2}}{\sqrt{1-r^{2}}}
$$

Dimana :

$\mathrm{t}=$ Derajat pengaruh

$r \quad=$ Koefisien korelasi

$\mathrm{n}=$ Jumlah sampel 


\section{PEMBAHASAN}

Hasil penelitian ini menunjukan bahwa ada korelasi yang sedang antara rekrutmen dengan kinerja pemerintah di Desa Analutur Kematan Babar Timur Kabupaten Maluku Barat Daya sebesar 0,789. Dengan demikian maka korelasi antara rekrutmen aparatur Terhadap kinerja pemerintah sebesar 0,789 adalah positif yang kuat. Dalam artian setiap terjadi peningkatan atau penurunan sebesar 0,789 apabilah variabel lain dianggap konstan. Hal ini jdapat dijelaskan sebagai berikut

\section{Rekrutmen}

Rekrutmen merupakan proses komunikasi dua arah. Pelamar-pelamar menghendaki informasi yang akurat mengenai seperti apakah rasanya bekerja di dalam organisasi bersangkutan. Organisasi-organisasi sangat menginginkan informasi yang akurat tentang seperti apakah pelamar-pelamar tersebut jika kelak mereka diangkat sebagai pegawai.

Sebanyak 1 orang $(2 \%)$ menyatakan bahwa tingkat pendidikan yang dimiliki oleh aparatur desa Analutur tingi, Sebanyak 28 orang (56\%) menyatakan bahwa tingkat pendidikan yang dimiliki oleh aparatur desa analutur sedang, dan 21 orang (42\%). Selanjutnya tidak ada menyatakan bahwa tingkat pendidikan yang dimiliki oleh aparatur desa rendah.orang yang menyatakan bahwa skill/keahlian yang dimiliki oleh aparatur desa Analutur tingi, Sebanyak 23 orang (46\%) menyatakan bahwa skill/keahlian yang dimiliki oleh aparatur desa Analutur sedang, dan 27 orang (54\%) menyatakan bahwa skill/keahlian yang dimiliki oleh aparatur desa Analutur rendah.

Selanjutnya tidak ada yang menyatakan bahwa pengalaman dimiliki oleh aparatur desa Analutur tinggi, 10 orang ( 20\%) menyatakan bahwa pengalaman yang dimiliki oleh aparatur desa Analutur sedang, Dan 40 orang yang menyatakan bahwa pengalaman yang dimiliki oleh aparatur desa Analutur rendah.

\section{Kinerja}

Setelah melakukan pemeriksaan terhadap beberapa Jawaban responden tentang indikator-indikator pada variabel terpengaruh (variabel Y), dapat dipresentasi secara mendetail terkait dengan tanggapan/jawaban responden terhadap indikator kinerja sebagai berikut Tidak ada orang yang menyatakan bahwa disiplin kerja yang dimiliki oleh aparatur desa tinggi, Sebanyak 28 orang (56\%) menyatakan bahwa disiplin kerja yang dimiliki oleh aparatur desa sedang, dan 22 
orang yang menyatakan disiplin kerja yang dimiliki oleh aparatur desa rendah.

Selanjutnya Tidak ada orang yang menyatakan bahwaloyalitas kerja yang dimiliki oleh aparatur desa tinggi, sebanyak 31orang atau (62\%) menyatakan bahwa loyalitas kerja yang dimiliki oleh aparatur desa sedang, Dan 19 orang (38 $\%)$ yang menyatakan bahwaloyalitas kerja yang dimiliki oleh aparatur desa rendah. Selanjutnya Tidak ada orang yang menyatakan bahwa prestasi kerja yang dimiliki oleh aparatur desa tinggi, sebanyak oleh aparatur desa sedang, dan 22 orang (44 \%) yang menyatakan bahwaloyalitas kerja yang dimiliki oleh aparatur desa rendah.

\section{Hubungan Antara Rekrutmen Dengan}

\section{Kinerja}

Dalam rangka untuk mengetahui hubungan anatara variabel bebas dan variabel terikat, maka diperlukan tabel kerja. Tabel kerja dibuat agar dapat menghimpun keseluruhan jawaban responden mengenai indikator-indikator yang telah diformulasikan dalam bentuk pertanyaan yang diajukan kepada seluruh responden. Hubungan anatara variabel pengaruh $(\mathrm{x})$ dan variabel terpengaruh $(\mathrm{Y})$ diperoleh datanya :

\begin{tabular}{|c|c|c|c|c|c|c|}
\hline$\sum$ & 213 & 238 & 943 & 1166 & 1041 & $\begin{array}{c}\mathrm{n}= \\
50\end{array}$ \\
\hline
\end{tabular}

Dari data di atas dapat dilakukan perhitungan Korelasi Person Product Moment sebagai untuk mengetahui hubungan antara rekrutmen dengan kinerja sebesar 0,789. Nilai ini menunjukan tingkat keterhubungan yang sedang antara rekrutmen dengan kinerja Pemeritah di Desa Analutur Kecamatan Babar Timur Kabupaten Maluku Barat Daya.

Dari hasil perhitungan terhadap koefisien determinan di atas membuktikan bahwa variabel rekrutmen memberikan kontribusi terhadap variabel kinerja sebesar $62,2 \%$ dan sisanya $37,8 \%$ ditentukan oleh variabel yang lain.

Selanjutnya untuk mengetahui signifikan tidaknya hubungan tersebut, maka diuji signifikannya dengan menggunakan uji t-hiutng dimana hasil perhitunggnya menunjukan bahwa besarnya t-hitung adalah 8,888. Bila dibandingkan dengan t-hitung pada tabel maka t- hitung lebih besar dari t-tabel pada taraf kepercayaan 0,05 yakni 8,888 $\geq 1,68$.

\section{Kesimpulan.}

Di bawah ini akan dikemukakan kesimpulan yang berhubungan dengan kedua variabel pokok dalam penelitian. Kesimpulan yang dikemukakan hanyalah bersifat umum dan tidak bersifat khusus, 
dalam arti dapat di uraikan setiap indikator yang dijadikan ukuran pada setiap variabel.

1. Di Desa Aanalutur Kecamatan Babar Timur Kabupaten Maluku Barat Daya masih menggunakan tradisi/adat yang diwarisi yang mengharuskan sosok pimpinan harus berasal dari Soa Onarloy Dan Soa Oraile.

2. Melalui hasil perhitungan korelasi, ternyata antara kedua variabel tersebut terdapat hubungan positif sebesar, 0.789. Nilai tersebut membuktikan bahwa antara variabel Rekrutmen dan variabel kinerja terdapat pengaruh yang signifikan.

3. Dengan demikian, maka apabila rekrutmen diterapkan dengan baik maka akan meningkatan kinerja pemerintah. Dengan kata lain bahwa menerima hipotesis yang menyatakan ada pengaruh antara rekrutmen dengan kinerja.

\section{Saran}

Dalam penulisan ini ada beberapa poin yang menjadi saran yaitu :

1. Pemerintah Desa Analutur Kecamatan Babar Timur Kabupaten Maluku Barat Daya perlu memperhatikan beberapa kriteria yang masih sangat kurang/rendah dapat terlihat pada variabel $\mathrm{X}$ (Rekrutmen) dengan indikatorindikator yakni, indikator tingkat pendidikan, dan skill/keahlian sedangkan pada variabel $\mathrm{Y}$ (Kinerja) dengan indikatorindikator disiplin kerja, loyalitas kerja, prestasi kerja

2. Rekrutmen Aparatur Desa dengan kinerja pemerintah menpunyai pengaruh yang kuat terhadap Prestasi Kerja Aparatur Pemerintah Desa Analutur Kabupaten Maluku Barat Daya sehingga diharapkan rekrutmen aparatur pemerintah di desa Analutur diterapkan secara baik.

3. Pimpinan harus mampu menciptakan hubungan harmonis dua arah secara baik dengan perkembangan organisasi kedepan, baik antara atasan dengan bawahan maupun bawahan dengan bawahan;

4. Dalam proses perekrutan aparatur desa, haruslah didasarkan pada beberapa kriteria seperti tingkat pendidikan, skill/keahlian, dan pengalaman kerja sehingga dalam melaksanakan tugas pelayanan kepada masyarakat, dapat sesuai dengan harapan bersama; 
5. Dalam proses perekrutan aparatur desa, janganlah menggunakan sistem kekeluargaan/nepotisme karena akan menghasilkan aparatur yang tidak berbobot;

6. Karena sampai saat ini pemerintah kabupaten Maluku barat daya belum memiliki regulasi dalam perekrutan aparatur desa, dan masih menggunakan PERDA Kabupaten MTB No 04 tahun 2006 tentang Persyaratan, Tata Cara Pengangkatan Dan Pemberhentian Perangkat Desa maka Pemerintah Desa Analutur Khususnya kepala desa terpilih haruslah menggunakan acuan yang ada untuk merekrut Aparatur Desa

7. Pemerintah Daerah Kabupaten Maluku Barat Daya haruslah membuat regulasi tentang Desa Adat atau Desa Negeri

\section{DAFTAR PUSTAKA}

Alaslan, Amtai (2021). Analilis Nilainilai Budaya Duan Lolat Berbasis Kearifan Lokal Pada Masyarakat Tanimbar di Kabupaten Maluku Tenggara Barat. Jurnal OTONOMI Ilmu Administrasi Vol. 11. No. 22: 80-96

Simamora,Henry,1997. Manajemen Sumber Daya Manusia. STIE YKPN, Yogyakarta.

Cardoso Gomes Faustino,1995. manajemen sumber daya manusia. $\mathrm{cv}$ andi offset,Yogyakarta

Noe, R.A et.al 2000. HUMAN Resource manajgement. USA Mc.Graw HIL

Maryoto Susilo,2007. Manajemen Sumber Daya Manusia. BPFE, Yogyakarta

Gibsn james L,et al 1996. organisasi: perilaku,struktur, prosesditerjemahkan olehninuk adriani. Binapura aksara,Jakarta

Drs. Soekarno K. 1980. Dasar-Dasar Manajemen. Mismar, Jakarta

Siagian P.sondang. 2002. Kiat Meningkatkan Produktivitas Kerja, rieneka cipta. Jakarta

Siagian. 1989. Teori Motivasi Dan Aplikasi, Bina Aksara, Jakarta.

Mathis R.L \& J,H Jackson 2006. Human Resource Management: Manajemen Sumber Daya Manusia, Terjemahan Dian Angelia, Salemba Empat, Jakarta 